\title{
Academic Performance of Senior Secondary School Students: Influence of Parental Encouragement and School Environment
}

\author{
Anshu Narad \& Bilkees Abdullah \\ Lovely Professional University, Phagwara
}

\begin{abstract}
Parental encouragement can nurture the hidden potentialities in children and lead to success in different walks of life. Academic performance is one of the important goals of education and has always been influenced by number of factors including parental encouragement and school environment. Keeping this in view a study was conducted to explore the parental encouragement and school environment of senior secondary school students and to analyze their relationship with academic performance of students. The study was descriptive survey in nature and simple random sampling technique was used for selection of the sample. The participants in the study included 300 senior secondary school girls (150 girls from each type of school i.e. co-education schools and girls' schools, out of each school 30 girls). For analysis of data, parametric statistical techniques were used. The study revealed that senior secondary school girls studying in co- education schools and girls' school had similar academic performance. Senior secondary school girls studying in girls schools had higher parental encouragement as compared to their counterparts in coeducational schools. Senior secondary schoolgirls studying in co-educational schools had higher permissiveness as compared to those studying in girls' school, while those in girls' school had higher control as compared to their counterparts in co-education schools. Significant positive relationship was found between academic performance of senior secondary school girls with parental encouragement and school environment.
\end{abstract}

Keywords: Academic Performance, Parental Encouragement, School Environment, Senior Secondary Schools.

\section{INTRODUCTION}

\section{Academic Performance}

Academic performance of students is the centre around which the whole education system revolves. The success and failure of any educational institution is measured in terms of academic performance of students. Not only the schools, but parents also have very high expectations from students with respect to their academic performance, as they believe that better academic results may lead to better career options and future security. Academic performance refers to the knowledge attained and designated by marks, assigned by teacher. In educational context, academic performance is the educational goal to be achieved by a student, teacher or institution over a certain period and is measured either by examinations or continuous assessments and the 
goal may differ from one individual or institution to another. Academic performance is the outcome of education, the extent to which a student, teacher or institution has achieved their educational goals. Academic anxiety and academic achievement were inversely and significantly related to each other (Murthy and Kulshreshta,1999). Academic performance of an individual is influenced by various factors such as personality, intellectual ability, environment, etc.

\section{Parental Encouragement}

Parental encouragement implies treatment provided by parents to their children, which can nurture the hidden potentialities with them. It can be in the form of guidance, concern, care, an approval by them and can act as a driving force for the children to take a particular decision in life. Parents' guidance, care and support especially in the area of education can make or mar the career of the children. Parent's timely support and guidance can work wonders. In fact parental encouragement can help the child in overcoming various difficulties in life, especially in the area of academics. When parents approve or disapprove of any activity concerning education or remove any difficulties felt by students in the process, or guide them about good or bad- all these activities come within the purview of parental encouragement (Rossi, 1965). In view of Agarwal (1999) parental encouragement is perceived by the child. Parental encouragement is one such aspect pertaining to home which helps the child to develop good ideas, habits, modes of thinking and behavior which makes the task of the school easy and ensure good study habits in children. Parental encouragement can be conceptualized as a treatment that originates from parents for the child so as to increase the likelihood of future occurrence of good behavior. Parental encouragement can be in different forms such as attending school functions, responding to the school obligations, involvement in children school work, arranging for appropriate study, time and space, molding desired behavior and guiding them as per the instructions of teachers. Parent's encouragement, in almost any form, produces measurable gain in student's achievement. Several researches agree that parental interest and family environment has a positive influence on the academic achievement of students (Howell and Frese, 1982; Gutman and McLoyd, 200o; Andera, 2001; Singh, 2003; Bajwa, 2006; Chabra and Kumari, 2011). Undeniably, parental encouragement is very much needed at every stage of life for coping with the life in a satisfactory manner.

\section{School Environment}

After the home, the school shares an important space in child's life and there exists distinctive combination between the two. School environment refers to the school psychological environment (Macchr and Midgley, 1991). School environment refers to the psycho-social climate of the school as perceived by the students. School environment is defined as the quantity and quality of emotional, social and cognitive support available to the students throughout their school life in terms of interaction between student and teacher (Mishra, 200o). School environment encompasses both the socio-psychological and physical dimensions, and both exercise a reciprocal effect on each other (Ames,1992). It refers to the extent to which student safety and student health are supported by school settings and may include aspects as the physical plant, the scholastic environment, availability of supports and services for promoting well being of students and provision of fair and adequate disciplinary rules and regulations. (Zais, 2011).The school environment can play an active role in promoting the all round development of children. Healthy environment in the school helps the child in making social adjustment. Satisfaction of child with the behavior of class follows, teachers, head of the institution, methods of teaching, time table, co-curricular activities influence his performance in academics, adjustment in life and society. The child spends most of his time in school, and this environment 
exerts a different influence on his performance through curricula, teaching techniques and relationship between teacher and student. School climate had a significant influence on the academic performance of students. (Makewa, Role, and Yegoh, 2011).

Parental encouragement and school environment are the two main important factors which play a significant role in one's academic performance. During the past few decades, much research has been undertaken to search the variables that determine the academic performance. However, the conjoint influence of parental encouragement and school environment on academic performance of students could hardly be found the literature. It is important to know how these two variables can influence the academic performance. Keeping this in view the study was conducted so as to fulfill the following objectives:

\section{Objectives}

\section{Following objectives were framed in the study:}

- To explore the academic performance, parental encouragement and school environment of senior secondary school girls.

- To compare senior secondary school girls studying in co-education schools and girls schools with respect to their -

- Academic performance

○ Parental encouragement

○ School environment

- To find out the relationship of academic performance of senior secondary school girls with their parental encouragement and school environment.

\section{Hypotheses}

1. There exists no significant difference in academic performance of senior secondary school girls studying in co- education schools and girls' school.

2. There exists no significant difference in parental encouragement of senior secondary school girls studying in co- education schools and girls' school.

3. There exists no significant difference in school environment of senior secondary school girls studying in co- education schools and girls' school.

4. There exists no relationship of academic performance of senior secondary school girls with their parental encouragement and school environment.

\section{Method and Procedure}

Descriptive survey method was used in the study. Data collection was done from girl students studying in ten schools (five co-education schools and five girls' schools) of Baramulla district of Jammu and Kashmir, by employing sample random sampling technique. The sample comprised of 300 senior secondary school girls (150 girls from each type of school i.e. co-education schools and 
girls schools, out of each school 30 girls). Two psychological tests were used to collect the data, one was "parental encouragement scale" developed by Dr. Kusum Agarwal (1999) and the second tool, "school environment inventory" was developed by Dr. Karuna Shankar Mishra (200o). To study the academic performance, the total marks obtained by the girl students at Matriculation level under Jammu and Kashmir Board of School Education was taken into consideration. Parametric statistical techniques were used for analysis of data. To explore the current status in terms of parental encouragement and school environment of senior secondary school girls, mean and standard deviation were calculated and for testing the significance of difference between means of parental encouragement, school environment and academic performance, $t$-test was applied. To analyse the relationship between academic performance of senior secondary school girls with parental encouragement and school environment multiple correlation was calculated.

\section{Results and Discussion}

Analysis of data, result and interpretation of findings have been done variable wise keeping in view the objectives of the study.

- Results relating difference between senior secondary school girls in academic performance

The below given table shows the differences in mean scores of academic performance for senior secondary school girls studying in co- education schools and girls schools

TABLE 1

MEAN SCORES OF ACADEMIC PERFORMANCE FOR SENIOR SECONDARY SCHOOL GIRLS STUDYING IN CO- EDUCATION SCHOOLS AND GIRLS SCHOOLS

\begin{tabular}{|l|l|l|l|l|l|l|}
\hline \multirow{2}{*}{$\begin{array}{l}\text { Academic } \\
\text { Performance }\end{array}$} & \multicolumn{2}{|l|}{ Co-Education Schools } & \multicolumn{2}{|l|}{ Girls Schools } & t-value & $\begin{array}{l}\text { Level of } \\
\text { significance }\end{array}$ \\
\cline { 2 - 6 } & Mean & S.D & Mean & S.D & & \multirow{2}{*}{ Not significant } \\
\cline { 2 - 6 } & 359.97 & 59.80 & 364.97 & 59.83 & .73 & \\
\hline
\end{tabular}

A look at the above table reflects mean scores and standard deviation of academic performance for senior secondary school girls studying in co- education schools and girls' schools. Further, the t-value calculated with regard to academic performance of senior secondary school girls studying in co- education schools and girls' school was found to be insignificant at 0.05 level. It can further be explained that senior secondary school girls studying in co- education schools and girls' school had similar academic performance. On the basis of above mentioned findings, it can be stated that the hypothesis no.1 i.e. "there exists no significant difference in academic performance of senior secondary school girls studying in co- education schools and girls' school” is thus accepted.

- Results relating difference between senior secondary school girls in parental encouragement

The table given below shows the difference in mean scores of parental encouragement for senior secondary school girls studying in co- education schools and girls schools 
MEAN SCORES OF PARENTAL ENCOURAGEMENT FOR SENIOR SECONDARY SCHOOL GIRLS STUDYING IN CO- EDUCATION SCHOOLS AND GIRLS SCHOOLS

TABLE 2

\begin{tabular}{|l|l|l|l|l|l|l|}
\hline \multirow{4}{*}{$\begin{array}{l}\text { Parental } \\
\text { Encouragement }\end{array}$} & \multicolumn{2}{|l|}{ Co-education School } & \multicolumn{2}{c|}{ Girls Schools } & t-value & $\begin{array}{l}\text { Level of } \\
\text { significance }\end{array}$ \\
\cline { 2 - 6 } & Mean & S.D & Mean & S.D & & 0.01 \\
\cline { 2 - 6 } & 318.63 & 40.54 & 333.83 & 35.95 & 3.44 & \\
\hline
\end{tabular}

A look at the above table reflects mean scores and standard deviation of parental encouragement for senior secondary school girls studying in co- education schools and girls schools. Further, the t-value calculated with regard to parental encouragement of senior secondary school girls studying in co- education schools and girls' school was found to be significant at o.o1 level. It can further be explained that senior secondary school girls studying in girls schools had higher parental encouragement as compared to those studying in co-education schools. It infers that senior secondary school girls studying in girls schools perceive greater parental encouragement as compared to those studying in co- education schools. On the basis of above mentioned findings, it can be stated that the hypothesis no.2 i.e. "there exists no significant difference in parental encouragement of senior secondary school girls studying in co- education schools and girls school" is thus rejected.

- Results relating difference between senior secondary school girls in school environment

The table shows the difference in mean scores of school environment for senior secondary school girls studying in co-education schools and girls' schools

MEAN SCORES OF SCHOOL ENVIRONMENT FOR SENIOR SECONDARY SCHOOL GIRLS STUDYING IN CO- EDUCATION SCHOOLS AND GIRLS SCHOOLS

TABLE 3

\begin{tabular}{|c|c|c|c|c|c|c|}
\hline School Environment & $\begin{array}{r}\text { Co-e } \\
\text { sc }\end{array}$ & $\begin{array}{l}\text { cation } \\
\text { ol }\end{array}$ & Girls s & 1001 & t-value & $\begin{array}{l}\text { Level of } \\
\text { significance }\end{array}$ \\
\hline \multirow[b]{2}{*}{ Creative Stimulation } & Mean & S.D & Mean & S.D & \multirow[b]{2}{*}{1.01} & \multirow[b]{2}{*}{ Not significant } \\
\hline & 58.07 & 4.42 & 58.51 & 3.13 & & \\
\hline Cognitive Encouragement & 30.47 & 4.12 & 30.41 & 3.97 & .143 & Not significant \\
\hline Permissiveness & 31.83 & 2.74 & 31.22 & 2.52 & 2.01 & 0.05 \\
\hline Acceptance & 29.49 & 2.16 & 29.29 & 2.24 & .785 & Not significant \\
\hline Rejection & 18.69 & 4.24 & 18.07 & 4.62 & 1.19 & Not significant \\
\hline
\end{tabular}




\begin{tabular}{|l|l|l|l|l|l|l|}
\hline Control & 28.83 & 3.11 & 29.73 & 3.31 & 2.40 & 0.05 \\
\hline
\end{tabular}

The above table reflects mean scores and standard deviation of school environment for senior secondary school girls studying in co-education schools and girls' schools. Further, t-values calculated for creative stimulation, cognitive encouragement, acceptance and rejection dimensions of school environment of senior secondary school girls studying in co-education schools and girls' schools was found to be insignificant while, the t-values calculated for permissiveness and control dimensions of school environment of senior secondary school girls studying in co-education schools and girls' schools was found to be significant at o.o1 level. It can further be explained that senior secondary school girls studying in co- education had higher permissiveness as compared to those studying in girls' school, while those studying in girls' school had higher control as compared to their counterparts in co-education schools. It infers that too much of restrictions are imposed and less opportunities are be provided to girls to express their views freely in girl's school as compared to their co-education counterparts. On the basis of above mentioned findings, it can be stated that the hypothesis no.3 i.e. "there exists no significant difference in school environment of senior secondary school girls studying in co- education schools and girls schools" is thus accepted.

- Results relating to relationship of academic performance of senior secondary school girls with their parental encouragement and school environment

TABLE 4

\begin{tabular}{|c|c|c|c|c|c|c|c|c|}
\hline \multicolumn{3}{|c|}{ Type of Variables } & Mean & S.D & $\mathbf{N}$ & $\mathbf{R}$ & \multirow{2}{*}{\multicolumn{2}{|c|}{$\begin{array}{l}\text { Interpretation } \\
\text { Level of } \\
\text { significance }\end{array}$}} \\
\hline \multirow{7}{*}{ Independent } & \multicolumn{2}{|c|}{ Parental Encouragement } & 326.23 & 39.01 & \multirow{8}{*}{300} & & & \\
\hline & \multirow{6}{*}{$\begin{array}{l}\text { School } \\
\text { Environment }\end{array}$} & $\begin{array}{l}\text { Creative } \\
\text { stimulation }\end{array}$ & 58.29 & 3.83 & & 0.95 & \multirow{7}{*}{$\begin{array}{l}0.05 \\
0.113\end{array}$} & \multirow{7}{*}{$\begin{array}{l}0.01 \\
0.148\end{array}$} \\
\hline & & $\begin{array}{l}\text { Cognitive } \\
\text { encouragement }\end{array}$ & 30.44 & 4.04 & & 0.98 & & \\
\hline & & Permissiveness & 31.53 & 2.64 & & 0.97 & & \\
\hline & & Acceptance & 29.39 & 2.20 & & 0.97 & & \\
\hline & & Rejection & 18.38 & 4.44 & & 0.97 & & \\
\hline & & Control & 29.28 & 3.24 & & 0.95 & & \\
\hline Dependent & \multicolumn{2}{|c|}{ Academic Performance } & 362.47 & 59.77 & & & & \\
\hline
\end{tabular}

The table shows the relationship of academic performance of senior secondary school girls with their parental encouragement and school environment. The coefficient of multiple correlation found was significant at 0.05 and 0.01 level. The result shows the calculated value of coefficient of multiple correlation of academic performance senior secondary school girls with their parental encouragement and school environment is positive. This indicates that parental encouragement and school environment together influence the academic performance of senior secondary school girls. This can further be explained that parental encouragement and school environment conjointly affect the academic performance of senior secondary school girls. If the senior secondary school girls have high level of parental encouragement and school environment then girls are likely to show higher level of academic performance. On the basis of above 
mentioned result hypothesis 4, "there exists no relationship of academic performance of senior secondary school girls with their parental encouragement and school environment" is thus rejected.

\section{Conclusions}

\section{The study documents the following conclusions:}

- Senior secondary school girls studying in co- education schools and girls' schools did not differ significantly with respect to their academic performance. Senior secondary school girls studying in co-education schools and girls' schools had similar academic performance.

- Senior secondary school girls studying in co-education schools and girls' schools differ significantly with respect to their parental encouragement. Senior secondary school girls studying in girls schools had higher parental encouragement as compared to their counterparts in co- education schools.

- Senior secondary school girls studying in co- education schools and girls' schools did not differ significantly in creative stimulation, cognitive encouragement, acceptance and rejection dimensions of school environment, but differed significantly with respect to permissiveness and control dimensions. Senior secondary school girls studying in coeducation had higher permissiveness as compared to those studying in girls' schools, while those studying in girls' school had higher control as compared to their counterparts in coeducation schools.

- Parental encouragement and school environment conjointly affect the academic performance of senior secondary school girls. If the senior secondary school girls have high level of parental encouragement and school environment then girls are likely to show higher level of academic performance

\section{References}

Agarwal, K. (1999). Parental Encouragement Scale. Agra: National Psychological Corporation, Agra.

Ames, C. (1992). Classroom: Goals Structure and Student Motivation. Journal of Educational Psychology, 84, 261-271.

Andera (2001). Effects of Family Environment and Pro-Social Behavior in Eastern and Western Countries. Journal of Research on Adolescence, 19, 9-34.

Bajwa, S. (2006). Academic Achievement in Relation to Family Environment and Academic Stress. Education New Horizons 4, 33-37.

Chabra, S. \& Kumari, L. (2011). Effect of Parental Encouragement on Achievement Motivation of Adolescents. International Journal of Education \& Allied Sciences, 373-78.

Gutman, L. M. \& McLoyd, V. C. (2000). Parents' Management of their Children's Education within the Home, at School, and in the Community: An Examination of African-American Families Living in Poverty. The Urban Review, 32, 1-24. 
Howell, F.M. \& Frese, W. (1982). Early Transition into Adult Roles: Some Antecedents and Outcomes. American Educational Research Journal, 19, 51-73.

Macchr, M.C. \& Midgley, C. (1991). Enhancing Student Motivation: A School-wide Approach. Educational Psychology, 26,399-427.

Makewa, L.N., Role, E. \& Yegoh, E. (2011). School Climate and Academic Performance in High and Low Achieving Schools: Nandi Central District, Kenya. International Journal of Scientific Research in Education, 4, 93-104.

Mick, Zais. (2011). South Carolina School Environment Initiative. Columbia: South Carolina Department of Education. [Online available at http:ed.sc.gov/agency/ac/StudentInterventionservices/documents/SC-SchoolEnvoronmnetRFP-Nov2011.pdf

Misra, K. S.(200o). Manual for School Environment Inventory, Lucknow: Ankur Psychological Agency.

Murthy, C.G. \& Kulshreshtha, R. (1999). Academic Anxiety and Academic Achievement. Journal of Indian Education 2, 29-37.

Rossi, A.S. (1965). Transition to Parenthood, Journal of Marriage and Family, 30, 26-30.

Singh, A. (2003). Academic Achievement in Relation to Family Environment among High School Students. Education New Horizons, 4, 1.

Dr. Anshu Narad is Assistant Professor, School of Education, LPU, Phagwara.

Ms. Bilkees Abdullah is Research Scholar, School of Education, LPU, Phagwara 